This is the post print version of the article, which has been published in European Politics and Society. 2019, 20(3), 333-347.

http://dx.doi.org/10.1080/23745118.2018.1540157

\title{
Looking at Others in National Policy-making: The Construction of Reference Groups in Portugal and Spain from 2008 to 2013
}

\author{
Laia Pi Ferrer ${ }^{a *}$, Pertti Alasuutari ${ }^{a}$ and Leena Tervonen-Gonçalves ${ }^{b}$ \\ ${ }^{a}$ Faculty of Social Sciences, University of Tampere, Tampere, Finland; ${ }^{b}$ Unit of Pori \\ (Faculty of Social Sciences), University of Tampere, Pori, Finland
}

*Laia Pi Ferrer: University of Tampere, Faculty of Social Sciences, Kalevantie 4, FI33014, 33100 Tampere, Finland.

Phone: +358 503187496

e-mail: laia.pi.ferrer@uta.fi

Pertti Alasuutari: University of Tampere, Faculty of Social Sciences, Kalevantie 4, FI33014, 33100, Tampere, Finland.

Phone : +358 504211053

e-mail: pertti.alasuutari@uta.fi

Leena Tervonen-Gonçalves: University of Tampere, Unit of Pori, Pohjoisranta $11 \mathrm{C}$, POB 181, FIN-28101 Pori, Finland.

Phone: +358 503187492

e-mail: leena.tervonen-goncalves@uta.fi

*corresponding author: Laia Pi Ferrer (laia.pi.ferrer@uta.fi)

\section{ORCID:}

Laia Pi Ferrer https://orcid.org/0000-0001-8655-591X

Pertti Alasuutari http://orcid.org/0000-0003-4111-9641

This is an Accepted Manuscript of an article published by Taylor \& Francis in European Politics and Society on 31 October 2018, available online:

https://www.tandfonline.com/doi/full/10.1080/23745118.2018.1540157 


\section{Acknowledgements:}

The authors wish to acknowledge members of the Tampere Research Group for Cultural and Political Sociology for comments on earlier versions.

\section{Funding:}

This work was made possible by financial support from the Academy of Finland (grant numbers 276076 and 294183) and Emil Aaltonen Foundation whose assistance is appreciated.

\section{Disclosure statement:}

The authors declared no potential conflicts of interest with respect to the research, authorship, and/or publication of this article. 


\title{
Looking at Others in National Policy-making: The Construction of Reference Groups in Portugal and Spain from 2008 to 2013
}

\begin{abstract}
Why is it that when debating the economic crisis, actors in the Portuguese parliament invoke more frequently countries affected by the crisis, whereas actors in the Spanish parliament invoke economically well-off countries more often? This article explores this mystery by studying how and why certain countries are evoked in the decision-making process. The analysis reveals that the actors mention different countries to contextualize the nation. We argue the actors in these two countries resort to different reference groups to identify or distance the nation in this concrete period even if they present similar challenges.
\end{abstract}

Keywords: reference group, epistemic governance, parliamentary debates, economic crisis, Portugal, Spain

\section{Introduction}

Even though the nation-states are sovereign entities, existing research shows that the decision-making of national governments is interdependent; that is, 'policy decisions in a given country are systematically conditioned by prior policy choices made in other countries'(Simmons, Dobbin, \& Garrett, 2008, p. 7). In practice, this means that when politicians discuss new policies in national parliaments, one of the ways to justify their ideas is to refer to decisions or policies adopted in other countries (Alasuutari, 2016). There have also been studies analysing how this actually takes place. For instance, it has been claimed that there are cross-national differences in the frequency with which actors in national political debates appeal to other countries (Alasuutari \& Vähä-Savo, submitted; Tiaynen-Qadir, Qadir, \& Alasuutari, 2018). However, less attention has been paid to the countries that speakers invoke. From this viewpoint, it is interesting to study how commonly different countries are mentioned and why.

In this paper, we study and compare the references to other countries that the actors in the Portuguese and the Spanish parliaments resort to when debating policies 
from 2008 until 2013. Although one could expect similar referencing patterns of these two neighbouring countries which have both struggled with an economic crisis in recent years, our analysis indicates that, on average, politicians refer to different countries when justifying their views. That is, in Portugal politicians typically refer to Southern European crisis countries, whereas in Spain speakers allude to Northern European welloff countries. Therefore, our research aims to make understandable this difference by analysing how references to other countries are used in national policy-making in the aftermath of the recent economic crisis.

The paper is organized as follows. After discussing the theoretical framework of this article, we introduce the data and the methods used in analysing it. Then, we present our results divided into two sections: a descriptive analysis of the references made to other countries, and a qualitative analysis of the discourses employed in those references. Finally, we discuss our findings linking them to the larger theoretical framework and suggesting possibilities for future research.

\section{Identification as a process of synchronization}

With our analysis of the ways in which Members of Parliament (MPs) allude to other nation-states when constructing their arguments in parliamentary discussions, we aim to contribute to the wider theoretical discussion on how and in what ways policies and ideas from other countries shape national policy-making. In order to do that, we use the concept of reference group in analysing to what countries the MPs refer and how such references are used to compare and propose policies and ideas. We argue that this practice contributes to a synchronisation of national policies and trajectories.

By talking about policy synchronisation, we claim that national governments react to global events and to the reactions of other governments, hence contributing to the creation of global policy fashions and ideas (Alasuutari, 2014a, 2016). From this 
viewpoint, the main question is not whether national-states' policies converge or diverge (e.g., Bennett, 1991; Jordan, 2005; Knill, 2005). Rather, the emphasis is on the process, in other words, 'how states pay attention to each other's moves and how that affects their policymaking'(Alasuutari, 2016, p. 13).

Previous scholarship shows that alluding to the international community, for instance to the policies adopted in other countries, is common in debating policies in national parliaments, because it is an effective way to try and convince others of sensible and efficient policies(Alasuutari, 2016; Tiaynen-Qadir et al., 2018). In such persuasion work, politicians are careful in choosing the countries and regions to which they refer. Bermeo (1992) concludes that comparability -that is, the geographic proximity, cultural similarity and shared history-influences the direction in which political actors may look at. It has also been proposed that prestige has a role, as models and ideas from countries with high status can influence the considerations of political actors (Weyland, 2004). Therefore, actors in national policy-making do not resort to the international community randomly. Rather, they allude to certain countries that they consider proper examples for their justifications in the national context. As Omelicheva (2009) points out, the state's behaviour in policy-making is influenced by the reference group.

The idea of reference group was originally coined in social psychology; where Hebert Hyman (1942) defined it as the group in which an individual evaluates his or her own situation or conduct. However, this approach has been tackled also in political sociology and international relations literature, where it has been pointed out that the state leaders and political actors invoke external models to make and propose policies (e.g., Alasuutari, 2014b; Omelicheva, 2009; Rivera, 2004; Tervonen-Gonçalves, 2012). Political actors compare the national context with that of other nation-states to prove 
that ideas, policies and practices enacted in those countries are legitimate and appropriate sources of information to consider. Thus, it can be assumed that states also have reference groups (Omelicheva, 2009).

The idea of the existence of a reference group implies that the self is shaped and constituted within a group. As identity only exists in a relational context among entities, it needs differences in order to be defined (Connolly, 2002; Neumann, 1999; Tekin, 2010). The image and reality that we get from the others serve as a source of knowledge for the identification of the self (Todorov, 1992). Identity is also plausible when we think of organisations. Comparisons among organizations frame and form the identification process, whereby the self-identification as an organization is directly influenced by the others (Sevón, 1996). The imitation process or learning from others plays a role in the identity construction of the institutions and organizations (Czarniawska \& Sevón, 1996). Indeed, before learning or imitating, institutions need to identify themselves in relation to others. Secondly, they need to identify and construct desires (What would we like to be?). Thirdly, they require an identification of reality (What kind of situation is this like?), and finally, they need to identify the action or route to take (What is appropriate for us in this situation?) (Sevón, 1996). Furthermore, when framing problems and promoting changes, organizations compare the local situations with the ones of the others (Sahlin-Andersson, 1996; Tervonen-Gonçalves, 2012). The actors involved in the organizations tend to compare them with others considered analogous when defining the situations, positions and suggestions (SahlinAndersson, 1996; Sevón, 1996). Considering nation-states, national policies are also formed and constructed by comparing and identifying the domestic situation with that of other countries (Tervonen-Gonçalves, 2012). Hence, mentioning 'Others’ actors proceed to conceptualize, understand and define the 'Self' (Sevón, 1996). 
The idea of identifying the country’s position by using comparisons or mentions of other countries is part of epistemic governance, as actors use references to other countries as means to persuade and convince the audience about the particular idea that they promote (Alasuutari \& Qadir, 2014). For instance, an MP can use a comparison to emphasise a bad shape of the nation to demonstrate that some actions are needed. This comparison works as a warning for the audience to suggest a change and make it as evident as possible. Another MP can make use of other countries to portray a different picture, for example to demonstrate that the country is taking the correct direction and that no changes should be made in this respect. Yet, suggesting that the nation has taken the same path as some others can have two goals. On the one hand, it could be done to justify the correct trajectory that the country has taken because some others are doing the same, but on the other hand it could be a means to emphasize that the situation is not proper in none of those countries.

\section{Data and Methods}

The empirical data used in this study comprise floor debates in different key bills during the recent difficult economic situation in Portugal and Spain, covering the time span from 2008 up to the year 2013. The reason for choosing these two countries is that they constitute a good example of nation-states who suffer from the economic downturn (e.g., Andrade \& Duarte, 2011; Royo, 2013). This period has been selected as a case to study because it represents hard times in the political sphere, especially in Southern Europe, where there have been many political problems to be discussed and solved (e.g., Bosco \& Verney, 2012). It has been suggested that when searching for policy solutions to new and challenging problems, governments are likely to look for solutions from abroad (Dolowitz \& Marsh, 2000). Yet, following Hay (1999), we understand the crisis as a process of decisive interventions and transformations where the state is 
reconstituted, and thus, a moment where the identification process is reinforced. This makes the period studied here an interesting case to study the ways the references to other countries reflect national self-identification.

These two countries represent a good pair for comparison because of their geographical, historical and cultural ties as well as their similar social traits (e.g., Queirós, 2009; Sardica, 2014), being part of the same family of nations (Castles, 1993; Obinger \& Wagschal, 2001). On the other hand, they differ from each other; for example, Spain has much more population, about four times the population of Portugal (Blanchard \& Jimeno, 1995). In addition, Spain is richer than Portugal in terms of GDP per capita (e.g., World Bank database ${ }^{1}$ ).

From the aforementioned debates during this period, we have selected the floor debates from all the key bills that were a direct consequence of the economic situation such as plans of austerity, cutbacks, etc., in addition to all the annual state budget bills. The procedure of identifying the key reforms and bills was done by looking at the archives of the principal newspapers from both countries ${ }^{2}$ and studying the chronology of crises published by Observatório Sobre Crises e Alternativas, University of Coimbra $^{3}$. These sources of information were used neither to analyse the content nor the way in which the events were reported. Rather, they were used as a first step to identify different measures, reforms and plans done during that period in order to select the floor debate where the discussions of the reforms took place. As a result, a total of 134 parliamentary debates, 64 from Spain and 70 from Portugal were selected for analysis. Parliamentary debates form an interesting research material for the purpose of this study, as parliaments are forums where politicians justify their views by responding not only to what has been said previously in the parliament but also elsewhere. Thus, they constitute a good point of connection between global ideas and national interest. 
[Figure 1 near here]

Data analysis consisted of two stages (see Figure 1). In the first stage, we coded and quantified the appearance of all nation-states in any of the 134 debates. This allowed us to identify the countries frequently used in both cases and to recognize the parts of the debates where the other countries are evoked. In the second stage, we analysed the parts where there are references to other countries. In this stage, we applied a set of analytical tools called discourse analysis (DA) (e.g., Fairclough, 2003; Howarth \& Torfing, 2004; Wood \& Kroger, 2000). Following Howarth and Torfing (2004, p. 300) discourse is understood here as an 'ensemble of ideas and concepts through which meaning is given to social and physical phenomena'.

In practice, what we analysed in the parliamentary debates were the elements of the discourses_-ideas, concepts and categories — wherein the references to other countries are evoked. (e.g., Tervonen-Gonçalves, 2013). In the data analysis, the interest was in identifying different modes of evoking other countries. By 'modes' we mean different discourses wherein speakers allude to other countries. In that sense, we did not have any pre-established categories to test in the data; rather we identified them inductively. The aim was to create a categorisation that includes all cases - that is, all mentions of other countries can be fitted into it (Alasuutari, Bickman, \& Brannen, 2008).

With this data as a material and the purpose of this study, our classification is reasonable and practical, as it does not lose the richness and variety of the references. Yet it allows us to categorise properly different ways of using other countries in the parliamentary debates. In addition, it must be noted that the types of references to other 
countries identified are not mutually exclusive, as a single quote may include several modes as well as several countries associated.

\section{The frequencies and discourses of referencing other countries}

Our data show that in both of these two countries, European countries and the USA that is, Western countries, are mentioned more often than others. However, there are important differences in the countries that parliamentarians reference more frequently.

On the one hand, politicians in the Portuguese parliament refer more often to Spain, Greece and Ireland-that is, to countries more affected by the economic crisis. In contrast, parliamentarians in the Spanish parliament mention more frequently big and economically well-off countries such as Germany, France, and the USA, followed by Italy and the UK (see Table 1 and 2).

[Table 1 and 2 near here]

In order to make sense of these patterns, we need to analyse how and why the actors make use of references to other countries in parliamentary debates. Are there, for instance, differences in the ways in which other countries are alluded to in Spanish and Portuguese parliaments that would explain the different referencing patterns?

A careful analysis of all the data suggests that we can distinguish three ways of alluding to other countries in the parliamentary debates. One is simply that parliamentarians take the example of one or several other countries to contrast or compare their policies to those of their own country. By listing several countries, parliamentarians are engaged in constructing a reference group or utilizing a shared view of a group, even if they do not name the group. These implicit or named groups of 
countries can then be used for identification in two ways. One is to differentiate or distance the parliamentarian's own country from others. Alternatively, parliamentarians can identify their country with a reference group. In that sense, parliamentarians refer to other countries in their political talks to locate their country on a map which they assume their audience to share.

\section{Constructing a reference group}

Parliamentarians may mention a single country as an example to support their argument. As shown in the quote below from the Spanish parliament, Germany is mentioned as an example to show what Spain should do or at least consider.

The truth would be that the Spanish Government, despite what they have told us, almost does not do cutbacks; almost does not touch the areas that are more dispensable and sumptuary: the Monarchy, the Senate, some redundant ministries and especially the Army. It seems that the times do not pass and that tanks and submachine guns can’t be touched either. In Germany, when the crisis started, they cut $40 \%$ of the military spending, and it is not, of course, our case (Parliament of Spain, 11 January 2012, p. 19) ${ }^{5}$.

In many cases a reference group is constructed by listing more than one country in the same statement. In such examples, parliamentarians cluster different countries under the same reference group due to their similar characteristics regarding the issue in question. The case below from the Portuguese parliament shows how this works. In this particular case, the MP invokes Germany, Italy, the Netherlands, Greece, Finland and the UK as a group of countries in which governments are increasing the age of retirement to prove 
that Portuguese government is not the only one doing these types of unpopular reforms. Indeed, by presenting more than one example the parliamentarian shows how common the type of reforms are that he proposes.

I would like to remind you that Germany is making changes like these, that France is making changes like these, Italy is making changes like these, the Netherlands is making changes like these, like Greece, Finland and the UK. In many European countries, the average retirement age is indeed increasing, and this is now necessary to protect the system (Parliament of Portugal, 29 November 2013, p. 15).

In some cases the parliamentarians give an attribute to the countries in question. In the example above, in addition to listing countries in which the retirement age has been raised, the attribute is simply 'European countries', but the name given to the reference group can also be more specific. If the attribute can also be applied to one’s own country, mentioning it implies that 'we' should consider following on the same path. The case below from the Spanish data shows how an MP compares the situations of Germany, France, Italy and Spain by indicating that they are grouped together as the larger Eurozone countries and that indeed they should follow similar paths.

This is what we have understood, for large Eurozone countries. Keep in mind that Germany has already put it in its Constitution and that France and Italy are on the same path as Spain, to put it in the Constitution (Parliament of Spain, 23 August 2011, p. 23). 
Another means of clustering countries into reference groups is to resort to statistical comparisons and ranking lists. The MPs mention several countries in the same statement by positioning them in relation to each other: which ones are average, leaders and laggards. Here is one example from the Portuguese parliament, in which the MP wants to emphasize the disastrous situation of the debt in the majority of the EU countries, and to pinpoint that Portugal is not the worst:

It is interesting to note that Ireland, Greece, Spain, or the United Kingdom and France have much more disequilibrium in the budget between 2008 and 2010 than Portugal.

How much is the public debt? In Belgium, it corresponds to $97.2 \%$ of the Gross Domestic Product; in Greece 112.6\%; in France 76.1\%; and, in Italy 114.6\%, with $78.2 \%$ being the average of the Eurozone. For 2010, it is foreseen that in Belgium, the public debt will correspond to $101.2 \%$ of GDP; in Greece 124.9\%; in France 82.5\%; in Italy $116.7 \%$ and in the Eurozone, the average will be the 84\% of GDP. The Portuguese position is more favourable than the average of the Eurozone. In 2010, Greece, Belgium and Italy will be worse off than Portugal - in fact, the biggest debt imbalances will exist in the UK, Spain and Greece (Parliament of Portugal, 25 March 2011, p. 29).

\section{Distancing the country from other countries}

These different ways of evoking a reference group are used to position the parliamentarian's own country on a map. One strategy is to distance one's country from a group. As in the example below from the Portuguese parliament where a MP is pointing out a difference between Portugal and France, Sweden and Germany, arguing 
that it is different to become unemployed in Portugal than in these three countries. In this case, taking distance from the countries mentioned is used to imply that there should not be such a difference.

The draft law of the Left Block responds to an unqualified situation where the unemployment rises at the same time that social protection declines. Right now, we have over 300,000 people - men and women, entire families - who do not have a euro to live. Mr. Deputy, if this is to promise the best, then you are not on the left for sure, because being leftist is to respond to this social crisis, the social crisis of the people, to which the Socialist Party has an obligation to respond. It is not worth it, Mr. Deputy, to talk about replacement rates, because being unemployed in France, Sweden or Germany is not the same as being unemployed in Portugal - and the Honourable Member knows this very well. Because the salary level is quite different (Parliament of Portugal, 22 January 2010, p. 45).

Differentiating from other countries may also be used to prove that one's country is in a better position than the others. In that sense, the strategy of differentiation is to defend the country's policy. We can see this in the quote below from the Spanish parliament, where the MP is pointing out the good situation of Spain compared with France and Italy.

It is important to underline, ladies and gentlemen, that the refinancing needs of the Spanish Treasury are relatively low in terms of GDP when compared with those of other countries in our area. This is due to our relatively low level of 
indebtedness. Throughout 2010, the total refinancing of the Treasury will represent 13.7 percent of GDP. In France, this figure rises to 15 percent and in the case of Italy; it is around 20 percent of its gross domestic product (Parliament of Spain, 19 October 2010, p. 5).

On the other hand, distancing from others can be a means to demonstrate the bad position of the country. For instance, in the Portuguese quote below, the parliamentarian emphasizes the Portuguese problem by mentioning that Greece is better regarding the comparison.

What we have at this moment is that Portuguese companies are financing more than twice the average in the Eurozone, even more so than in Greece. Look, Mr. Minister! It is harder for a company to finance itself in Portugal than in Greece (Parliament of Portugal, 19 October 2012, p. 14).

The purpose of distancing the country from others might also be to show that the parliamentarians do not sympathize with certain policies enacted. In other words, MPs try to convince the audience of what they should not do by referring to other countries. Here is one example from the Portuguese parliament:

The example of Ireland, for years present in the speech of the right, is there to show us the recessive policies. Ireland was the first country to cut wages and raise taxes, as it is now defended by the Socialist Party and the Social Democratic Party, it is now the third country in the world in greater danger of a bankruptcy and it has the highest interest rates on public debt. In addition, this 
budget precisely wanted to perpetuate this spiral of degradation. Do not say, ladies and gentlemen, that this has to be the case. Just do not learn from the mistakes of others who insist on adopting them, even though with the awareness that they will cause harm. Look at Ireland, look at Greece: they have done what was considered in our SGP and in this Budget as a solution and the truth is that they are worse than before (Parliament of Portugal, 2 November 2010, p. 80).

\section{Identifying the country with other countries}

Another strategy of referring to other countries is to identify the country with some others. It is a means to make more sense of the domestic situation, but this time by pointing out similarities. As shown in the quote below from the Spanish parliament, where a MP is identifying Spain with Italy, Belgium and France to show that all of them have problems in the fluctuation of the risk premiums, and that the Spanish government is not the only one that is struggling with this situation.

In the sovereign debt markets of the Eurozone these uncertainties have once again led to significant fluctuations in risk premiums, with worrying and unjustified increases in countries such as Spain and Italy, but also in others, such as Belgium or France, whose risk premium has also reached its maximum levels since the creation of the euro; and the credit default swap, the so-called CDS, have approached 200 basis points (Parliament of Spain, 23 August 2011, p. 3).

In addition, parliamentarians might refer to other countries to express an aspiration. In such a case, a MP does not show similarities between their own country and the others mentioned at the present moment, but rather indicates the desire of identifying with 
them in the future. We can observe this type of reference in the quote below from the Spanish parliament, where the parliamentarian refers to Germany and the USA as good models for dealing with public debt. This reference serves as a suggestion for the Spanish government about how to react in the current situation.

That is why for years you have risen one tax after another-, while paradoxically, we are seeing that in other countries; as for example in Germany, they have not based their economic policy on that authentically Lutheran austerity that you exhibit. For example, in 2010, in Germany, the deficit grew to 5.4 percent of GDP, when in 2008 they still had a 0.2 percent surplus. How? Well, for example, helping companies to retain employment, especially those that generate exports. What have the political actors in the United Stated done? For instance, they have spent almost 790,000 million dollars and have created 3.3 million new jobs. That is, the public deficit, ladies and gentlemen, is like cholesterol, there is good and bad one (Parliament of Spain, 19 October 2010, p. 33).

The allusions to other countries are not only to serve as policy examples. Rather, they are also invoked to show that there is a problem, that indeed they are in a crisis. The analysis shows how Portuguese and the Spanish parliamentarians define the situation of their country by comparing it to other countries. On the one hand, parliamentarians may point out that, although the situation is serious, there are others who are in a much tighter spot. On the other hand, they can allude to other countries to prove how critical the situation is and to call for a proper solution. 
To recap, the data shows that parliamentarians use references to other countries in order to position their own country in relation to the others. In that way constructing reference groups was done by using different strategies: citing one or more countries, attributing a characteristic or a name to them and using ranking lists or statistical comparisons. Furthermore, these strategies are used to distance or identify the country with some others. The objective of such comparison is to convince others about the ideas that a speaker advocates.

\section{The difference between Spain and Portugal in international references}

Regarding cross-national comparisons, in these two national parliaments MPs use the same discursive strategies in referring to other countries. Besides, these two countries are similar in many respects, including the fact that they both faced problems related to the global financial crisis that started in 2008. So, what explains the different patterns in the ways in which parliamentarians refer to different countries when debating national policy-making?

The data shows that differences between Spanish and Portuguese parliamentarians' referencing patterns have to do with how commonly different clusters of countries are used as reference groups. One such cluster of countries is composed of Greece, Portugal, Spain, Ireland and less frequently Italy. These countries are recurrently lumped together when debating the economic situation, its problems and consequences. They are repeatedly grouped together as the 'crisis countries'. Let us take an example from the Portuguese parliament:

Portugal, Spain, Greece and Ireland face difficulties in the international financial markets and overcoming these difficulties imposes a large-scale budgetary demand and austerity (Parliament of Portugal, 2 November 2010, p. 96). 
Another group that appears recurrently in the debates is the cluster of what can be named economically well-off countries, typically composed of France and Germany, but also the UK, the USA and some other Northern European countries. In the majority of cases, these mentions are used to show the bad or disadvantaged situation in which the country is. Here is an example from the Spanish parliament:

The socialist model has impeded that the economic resources gave the results desired. That economic effort has resulted in significant changes such as that the expenditure per student in public education in our country is above our neighbouring countries such as France, Germany, the United Kingdom or Finland and yet our results are infinitely worse. Therefore, we are convinced that the improvement of the education system requires necessarily a change of model, a better rationalization of resources and more efficiency in their application (Parliament of Spain, 17 May 2012, p. 24).

It is the use of these two clusters, the "crisis countries" and the "well-off countries", in these two national parliaments that explain the differences in the referencing patterns. In the majority of cases in Portugal, speakers justify and explain their situation by resorting to the labelling of crisis countries: typically Spain, Greece and Ireland. In contrast, Spanish speakers distance or identify the country with Germany, France and the USA, countries that can be considered bigger and economically well-off. This does not mean that Spanish parliamentarians do not consider Spain being in a crisis; they just resort to a different reference group when explicating their views. 
Hence, the discursive strategies and purposes for referencing other countries in national political debates are similar in both countries. The differences in frequencies with which different countries are mentioned as examples stem from the use of different reference groups in political rhetoric.

\section{Discussion and Conclusions}

In this study we set out to analyse how the MPs make use of other countries when debating policies in the national parliaments. By studying the Portuguese and Spanish parliaments in the period from 2008 to 2013, we focused on a critical moment when these two countries of the Iberian Peninsula faced similar challenges. Even though these two countries can be grouped together for several reasons, their parliamentarians’ referencing patterns differed from each other. While Portuguese parliamentarians alluded to crisis countries more often, parliamentarians in the Spanish parliament appealed to the example of bigger and economically well-off countries more frequently.

The analysis shows that the parliamentarians construct reference groups by alluding to other countries in debating national policy-making. These reference groups can have different purposes in their talks. The MPs can mention other countries to distance the country from a reference group, but they can also allude to a cluster of countries to identify the nation with it. Therefore, the use of references to other countries in the parliamentary debates serves as a way to locate the nation on a map, to make the situation of the nation and the parliamentarian's view more illustrative and plausible. The analysis shows that the different referencing patterns in these two national parliaments stem from the tendency of politicians in these two countries to use different reference groups for explicating their views: Portuguese politicians allude to “crisis countries”, whereas Spanish politicians use "well-off” countries as their point of 
comparison. These different patterns may imply that citizens in these countries place their own country on the map of nations differently, but does not mean that Spanish parliamentarians refuse to admit that Spain is in a crisis; they just build their argument differently.

As discussed in this paper, taking other countries as examples and objects of comparison in political rhetoric can be characterized as identity work. Parliamentarians mention a particular country or group of countries to point out a policy success and consequently, propose a practical solution for one's own country due to the embedded assumption that these countries are similar. On the other hand, a policy enacted in a country can be objected by arguing that country is different from one's own. Hence, this kind of identity work understood as a contextualization process matters in political discourses.

As policymakers try to persuade the audience by arguing and providing examples from other countries, compatriots resort to certain reference groups in their political discourse because they are understandable, well-known and shared among the citizens. Frequent citations to some countries reflect a perceived affinity to them. This affinity to some countries can have different reasons such as geographical location, organizational memberships, or historical, cultural and socio-economic resemblances. This is evident in the important presence of EU countries or the USA as references, while Asian or African countries are almost non-existent. The fact that policymakers in Spain use more references to Germany or France is because, despite being a southern European and a crisis country, regarding the economy and population it is a big country, one of the big five in Europe. Therefore, Spanish parliamentarians resort more often to European that they consider similar, within the same category. Likewise, Portuguese parliamentarians appeal more often to countries that they consider part of the same 
league, such as the southern or crisis countries, because these ones make more sense to the national audience.

In this respect, the countries more frequently mentioned form the main reference group. In the national political discussion actors invoke these countries because they are familiar to and recognisable within the nation. Compatriots are familiar with the situation and policies of countries that are perceived as part of the same group. Within the reference group composed of countries that are most commonly mentioned in political rhetoric, there can be different types of countries — from countries that are admired to others that are considered similar, and to ones from which parliamentarians want to keep a distance. Among the immense possibilities of references to other nationstates, politicians use more repeatedly the ones they think work best in persuasion and are recognizable to the national audience.

Another broad aim of this study was to shed more light on how the synchronization of national policies through epistemic governance takes place. Considering the ways other countries are evoked and the role that they play in political rhetoric, we suggest that reference groups play a significant role in the synchronization of national policies. As political actors in nation-states keep an eye particularly on policies enacted in their reference group, national states end up synchronizing their moves with those closest to them culturally and politically. Consequently, the global travel of ideas does not mean that all national policies converge, but countries do react to the same major events and trends (Alasuutari, 2016).

Our study also supports previous arguments from Simmons and Elkins (2004), who point out that governments do not learn from policies enacted elsewhere randomly, but rather through intergovernmental networks established between culturally proximate countries. Additionally, our results align with Strang's and Meyer's ideas (1993), who 
argue that cultural similarities represent a key aspect facilitating cross-national policy transfer, as decision-makers will pay attention to the experiences of countries with which they share cultural ties. Several other scholars have also pointed out the importance of shared history and cultural affinities in policy learning and diffusion (e.g., Lenschow, Liefferink, \& Veenman, 2005; Omelicheva, 2009; Weyland, 2004). However, our study goes a step further by showing that although governments learn from different countries, depending on national context, MPs use the same discursive strategies with which they contextualize the nation through cross-national comparison. On the other hand, our results differ with Rivera’s (2004) suggestion, according to which policy-makers copy policies from other countries even regardless of cultural, geographical or historical ties.

Our analysis has limitations in terms of the material and time span as the empirical purpose was to focus on the parliamentary debates in these two countries during the recent economic crisis period. Therefore, we do not assume that these reference groups are specific to this period, nor that the reference groups do not change. It would be interesting for future research to analyse whether and how the reference groups vary in time, depending on the situations, ties and affinities of the moment or the aspirations of the nation. In addition, it could be interesting to study what are the countries within these reference groups that are used particularly to ridicule the national situation or to point out achievements. Finally, this study can be also extended to other countries and other public talks such as the national media.

\section{Notes}

1. The World Bank, Data Base. GDP per capita (current US\$) in Portugal and Spain. Available online at: 
https://data.worldbank.org/indicator/NY.GDP.PCAP.CD?locations=PT-

\section{$\underline{E S \& v i e w=c h a r t}$}

2. Both newspapers are about general information and they have a great rank in readers. El País is the most widely read general newspaper in Spain with 1.851 .000 readers per day [Data from the Asociación para la Investigación de Medios de Comunicación (Association for the research around media communication) from October 2012 to May 2013]. Correio da Manhã is the most widely read general newspaper in Portugal with 1.206.000 reader per day [Data from Barem Imprensa from 2014.]

3. Centre for Social Studies, University of Coimbra. Observatório Sobre Crises e Alternativas. Available online at: http://www.ces.uc.pt/observatorios/crisalt/cronologia.php

4. The tables only show the five countries more mentioned in each parliament. In the data set, there are other references to other countries. First, there is a predominance of European countries. Among the European countries, the Western ones are more invoked, whereas the Eastern ones are almost non-existent in their talks. In a second place, we can perceive references to big and powerful countries such as the USA and China. Thirdly, we can also notice how some former colonies have a presence in their discourses, although they are not as recurrent as some other countries. This is the case of Brazil, Angola and Mozambique or, Cuba and Argentina. In addition, it is observed how there are not many references to African and Asian countries.

5. All data excerpts are translated from Spanish and Portuguese by the authors. 


\section{References}

Alasuutari, P. (2014a). Following the example of other countries? Policy analysis of new legislation in Canada, the United Kingdom and the United States. Journal of Comparative Policy Analysis: Research and Practice, 16(3), 266-279.

Alasuutari, P. (2014b). Interdependent decision-making in practice: justification of new legislation in six nation-states. In P. Alasuutari \& A. Qadir (Eds.), National Policy-Making: Domestication of Global Trends (pp. 25-43). London: Routledge.

Alasuutari, P. (2016). The Synchronization of National Policies: Ethnography of the Global Tribe of Moderns. London: Routledge.

Alasuutari, P., Bickman, L., \& Brannen, J. (Eds.). (2008). The SAGE handbook of social research methods. Thousand Oaks, CA: Sage.

Alasuutari, P., \& Qadir, A. (2014). Epistemic governance: An approach to the politics of policy-making. European Journal of Cultural and Political Sociology, 1(1), 67-84.

Alasuutari, P., \& Vähä-Savo, V. (submitted). American exceptionalism in a comparative perspective. Manuscript submitted for publication.

Andrade, J. S., \& Duarte, A. (2011). The fundamentals of the Portuguese crisis. Panoeconomicus, 58(2), 195-218.

Bennett, C. J. (1991). What is policy convergence and what causes it? British Journal of Political Science, 21(2), 215-233.

Bermeo, N. (1992). Democracy and the lessons of dictatorship. Comparative Politics, 24(3), 273-291.

Blanchard, O., \& Jimeno, J. F. (1995). Structural unemployment: Spain versus Portugal. The American Economic Review, 85(2), 212-218. 
Bosco, A., \& Verney, S. (2012). Electoral epidemic: The political cost of economic crisis in Southern Europe, 2010-11. South European Society and Politics, 17(2), 129-154.

Castles, F. G. (1993). Families of nations: Patterns of public policy in Western democracies. Aldershot: Dartmouth.

Connolly, W. E. (2002). Identity/Difference: Democratic negotiations of political paradox Minneapolis: University of Minnesota Press.

Czarniawska, B., \& Sevón, G. (1996). Translating organizational change. Berlin: Walter de Gruyter.

Dolowitz, D. P., \& Marsh, D. (2000). Learning from abroad: The role of policy transfer in contemporary policy-making. Governance, 13(1), 5-23.

Fairclough, N. (2003). Analysing discourse: Textual analysis for social research. London: Routledge.

Hay, C. (1999). Crisis and the structural transformation of the state: Interrogating the process of change. The British Journal of Politics and International Relations, 1(3), 317-344.

Howarth, D., \& Torfing, J. (2004). Discourse theory in European politics: Identity, policy and governance. Basingstoke: Palgrave Macmillan.

Hyman, H. H. (1942). The psychology of status. Psychological Bulletin, 39, 473-474.

Jordan, A. (2005). Policy convergence: A passing fad or a new integrating focus in European Union studies? Journal of European Public Policy, 12(5), 944-953.

Knill, C. (2005). Introduction: Cross-national policy convergence: Concepts, approaches and explanatory factors. Journal of European Public Policy, 12(5), 764-774. 
Lenschow, A., Liefferink, D., \& Veenman, S. (2005). When the birds sing. A framework for analysing domestic factors behind policy convergence. Journal of European Public Policy, 12(5), 797-816.

Neumann, I. B. (1999). Uses of the other:" The east" in European identity formation. Manchester: Manchester University Press.

Obinger, H., \& Wagschal, U. (2001). Families of nations and public policy. West European Politics(24), 1.

Omelicheva, M. Y. (2009). Reference group perspective on state behaviour: A case study of Estonia's counterterrorism policies. Europe-Asia Studies, 61(3), 483504.

Parliament of Portugal (2010, 2 November). Orçamento do estado para 2011 [Budget of the state for 2011], (http://debates.parlamento.pt/catalogo/r3/dar/01/11/02/020/2010-1102/96?q=Espanha\&from $=2010-11-01 \&$ to $=2010-11-03)$.

Parliament of Portugal (2010, 22 January). Projecto de lei 12/XI- altera as regras da atribuição do subsídio de desemprego, introduzindo uma maior justiça social [Bill 12/XI- modification of the unemployment subsidy, introducing a bigger social justice],

(http://debates.parlamento.pt/catalogo/r3/dar/01/11/01/025/2010-01-

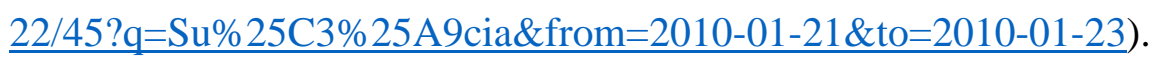

Parliament of Portugal (2010, 25 March). Programa de estabilidade e crescimento para 2010-2013 [Stability and growth programme for 2010-2013], (http://debates.parlamento.pt/catalogo/r3/dar/01/11/01/039/2010-0325/29?q=Espanha\&from $=2010-03-23 \&$ to $=2010-03-25)$. 
Parliament of Portugal (2012, 19 October). Sobre uma política alternativa para o país: Aumento da produção nacional, renegociação da dívida, melhor distribuição da riqueza [Alternative politics for the country: Increase of the national production, renegotiation of the debt, better distribution of the wealth], (http://debates.parlamento.pt/catalogo/r3/dar/01/12/02/013/2012-1018/14?q=Gr\%25C3\%25A9cia\&from=2012-10-17\&to=2012-10-20).

Parliament of Portugal (2013, 29 November). Procede à primeira alteração à lei n. ${ }^{\text {}}$ 42007, de 16 de janeiro, que aprova as bases gerais do sistema de segurança social [First modification of the law n. 42007, from 16 of January, which approves the general bases of the social security system], (http://debates.parlamento.pt/catalogo/r3/dar/01/12/03/022/2013-1129/15?q=Finl\%25C3\%25A2ndia\&from=2013-11-27\&to=2013-11-29)).

Parliament of Spain (2010, 19 October). Proyecto de ley de presupuestos generales del estado para el año 2011 [General State Budget for the year 2011], (http://www.congreso.es/public_oficiales/L9/CONG/DS/PL/PL_197.PDF).

Parliament of Spain (2011, 23 August). Real decreto-ley 9.2011, medidas para la mejora de la calidad y cohesión del sistema nacional de salud, de contribución a la consolidación fiscal, y de elevación del importe máximo de los avales del estado para 2011 [Royal Decree-Law 9.2011, measures to improve the quality and cohesion of the national health system, contributing to the fiscal consolidation, and raising the maximum amount of state guaranties during 2011], (http://www.congreso.es/public_oficiales/L9/CONG/DS/PL/PL_268.PDF).

Parliament of Spain (2012, 11 January). Real decreto-ley 20/2011, de 30 de diciembre, de medidas urgentes en materia presupuestaria, tributaria y financiera para la corrección del déficit público [Royal decree-law 20/2011 of 30 December, on 
urgent budgetary, fiscal and financial measures for the correction of the public deficit],

(http://www.congreso.es/public_oficiales/L10/CONG/DS/PL/PL_004.PDF).

Parliament of Spain (2012, 17 May). Real decreto-ley 14/2012, de 20 de abril, de medidas urgentes de racionalización del gasto público en el ámbito educativo [Royal decree-law 14/2012 of 20 April, on urgent measures to rationalise public expenditure in the field of education],

(http://www.congreso.es/public_oficiales/L10/CONG/DS/PL/PL_031.PDF).

Queirós, A. (2009). As relações luso-espanholas: do final da Primeira República à Revolução dos Cravos (1926-1974) [The Lusitanian-Spaniard relation: from the end of the First Republic to the Carnation Revolution (1926-1974)]. Agália: Publicação internacional da Associação Galega da Língua, 97, 199-208.

Rivera, S. W. (2004). Elites and the diffusion of foreign models in Russia. Political Studies, 52(1), 43-62.

Royo, S. (2013). How did the Spanish financial system survive the first stage of the global crisis? Governance, 26(4), 631-656.

Sahlin-Andersson, K. (1996). Imitating by Editing Success: The Construction of Organizational Fields. In B. Czarniawska \& G. Sevón (Eds.), Translating Organizational Change (pp. 69-92). Berlin: Walter de Gruyter.

Sardica, J. M. (2014). The cultural discourse of contemporary Portuguese Iberianism. International Journal of Iberian Studies, 27(1), 55-70.

Sevón, G. (1996). Organizational Imitation in Identity Transformation. In B. Czarniawska \& G. Sevón (Eds.), Translating Organizational Change (pp. 4967). Berlin: Walter de Gruyter. 
Simmons, B. A., Dobbin, F., \& Garrett, G. (2008). Introduction: The diffusion of liberalization. In B. A. Simmons, F. Dobbin, \& G. Garrett (Eds.), The Global Diffusion of Markets and Democracy (pp. 1-63). New York: Cambridge University Press.

Simmons, B. A., \& Elkins, Z. (2004). The globalization of liberalization: Policy diffusion in the international political economy. American Political Science Review, 98(1), 171-189.

Strang, D., \& Meyer, J. W. (1993). Institutional conditions for diffusion. Theory and Society, 22(4), 487-511.

Tekin, B. Ç. (2010). Representations and othering in discourse: The construction of turkey in the EU context. Amsterdam: John Benjamins Publishing.

Tervonen-Gonçalves, L. (2012). From averages to best performers: Use of comparisons in identity formation. Critical Policy Studies, 6(3), 304-323.

Tervonen-Gonçalves, L. (2013). International Ideas and National Agendas of Public Health Policy-the Cases of Finland and Portugal (Doctoral dissertation), University of Tampere, Tampere. Retrieved from http://tampub.uta.fi/handle/10024/68075

Tiaynen-Qadir, T., Qadir, A., \& Alasuutari, P. (2018). Russia in world society: A comparative perspective on international references in parliamentary debates. Acta Sociologica. doi:0001699317749287

Todorov, T. (1992). The conquest of America: The question of the other. New York: Harper Perennial.

Weyland, K. G. (2004). Learning from foreign models in Latin American policy reform. Washington DC: Woodrow Wilson Center. 
Wood, L. A., \& Kroger, R. O. (2000). Doing discourse analysis: Methods for studying action in talk and text. Thousand Oaks, CA: Sage.

\section{Figure and Tables}

Figure 1. Analytical framework

How and why is it that actors in national policymaking refer to other countries when debating and justifying national policies?

1. (First stage) Descriptive
analysis of the countries
alluded to in the
$\begin{gathered}\text { Portuguese and the Spanish } \\ \text { debates. } \\ \text { Are there any big } \\ \text { differences between these } \\ \text { two countries? }\end{gathered}$

Table 1 and 2. List of the top 5 countries mentioned in the parliamentary debates of Portugal and Spain ${ }^{4}$

\begin{tabular}{|c|c|c|c|c|c|}
\hline \multicolumn{3}{|c|}{ Top 5 countries in the Portuguese Parliament } & \multicolumn{3}{|c|}{ Top 5 countries in the Spanish Parliament } \\
\hline \multirow{2}{*}{ Countries } & \multicolumn{2}{|c|}{ Debates (N=70) } & \multirow{2}{*}{ Countries } & \multicolumn{2}{|c|}{ Debates $(N=64)$} \\
\hline & $N$ & $\%$ & & $N$ & $\%$ \\
\hline Spain & 36 & 51.4 & Germany & 39 & 60.9 \\
\hline Greece & 35 & 50.0 & France & 31 & 48.4 \\
\hline Ireland & 25 & 35.7 & United States & 28 & 43.8 \\
\hline Germany & 23 & 32.9 & Italy & 27 & 42.2 \\
\hline France & 22 & 31.4 & United Kingdom & 20 & 31.3 \\
\hline
\end{tabular}

